ARTICLE

Received 21 Jan 2014 | Accepted 28 Aug 2014 | Published 14 Oct $2014 \quad$ DOl: 10.1038/ncomms6091

\title{
Ultralow viscosity of carbonate melts at high pressures
}

Yoshio Kono', Curtis Kenney-Benson', Daniel Hummer ${ }^{2}$, Hiroaki Ohfuji ${ }^{3}$, Changyong Park', Guoyin Shen', Yanbin Wang ${ }^{4}$, Abby Kavner ${ }^{2}$ \& Craig E. Manning ${ }^{2}$

Knowledge of the occurrence and mobility of carbonate-rich melts in the Earth's mantle is important for understanding the deep carbon cycle and related geochemical and geophysical processes. However, our understanding of the mobility of carbonate-rich melts remains poor. Here we report viscosities of carbonate melts up to $6.2 \mathrm{GPa}$ using a newly developed technique of ultrafast synchrotron $X$-ray imaging. These carbonate melts display ultralow viscosities, much lower than previously thought, in the range of 0.006-0.010 Pas, which are $\sim 2$ to 3 orders of magnitude lower than those of basaltic melts in the upper mantle. As a result, the mobility of carbonate melts (defined as the ratio of melt-solid density contrast to melt viscosity) is $\sim 2$ to 3 orders of magnitude higher than that of basaltic melts. Such high mobility has significant influence on several magmatic processes, such as fast melt migration and effective melt extraction beneath mid-ocean ridges.

\footnotetext{
${ }^{1}$ HPCAT, Geophysical Laboratory, Carnegie Institution of Washington, 9700 South Cass Avenue, Argonne, Illinois 60439, USA. ${ }^{2}$ Department of Earth, Planetary and Space Sciences, University of California Los Angeles, 595 Charles Young Drive East, Box 951567, Los Angeles, California 90095, USA. ${ }^{3}$ Geodynamics Research Center, Ehime University, 2-5 Bunkyo-cho, Matsuyama 790-8577, Japan. ${ }^{4}$ GeoSoilEnviroCARS, Center for Advanced Radiation Sources, The University of Chicago, 5640 South Ellis Avenue, Chicago, Illinois 60637, USA. Correspondence and requests for materials should be addressed to Y.K. (email: ykono@ciw.edu).
} 
C arbonate-rich magmas are rarely erupted at the Earth's surface, but are important to Earth's magmatism at depth. Carbonatite is an igneous rock containing $>50 \%$ magmatic carbonate minerals that occurs on all continents, from the Archean to the present day ${ }^{1}$, and derives from carbonate-rich magmas in the upper mantle $e^{2-4}$. Kimberlite is another carbonate-rich magma, typically intruded into the crust of ancient and stable cratons ${ }^{5-7}$. Kimberlite magma is characterized by low silica with high magnesium and a $\mathrm{C}-\mathrm{O}-\mathrm{H}$ volatile-rich composition ${ }^{5-8}$, and is thought to be formed in the presence of $\mathrm{H}_{2} \mathrm{O}$ and $\mathrm{CO}_{2}$ under conditions close to the carbonate-peridotite solidus in the Earth's mantle ${ }^{9-11}$. Small amounts of carbonate-rich melt may also be present in the asthenosphere beneath mid-ocean ridges, according to recent electrical conductivity studies ${ }^{12,13}$ and high-pressure and hightemperature experiments ${ }^{10,14-16}$. In addition, strongly carbonated silicate melt is thought to be partly responsible for the presence of oceanic low-velocity zones ${ }^{10,17}$.

Despite extensive studies on the occurrence and stability of carbonate-rich melts, physical properties (such as density, viscosity and mobility) of carbonate melts have not been well-understood. Viscosity is one of the most important transport properties controlling migration processes of melts in the Earth's interior ${ }^{18}$. Viscosities of numerous silicate, oxide and metallic melts have been investigated by falling-sphere viscometry at high-pressure conditions ${ }^{19-25}$. By contrast, there are only limited experimental data on the viscosity of carbonate at high pressures and temperatures. One study reported viscosity of a melt with 70 wt. $\% \mathrm{CaCO}_{3}$ and 30 wt.\% $\mathrm{MgCO}_{3}$ at $1 \mathrm{GPa}$ (ref. 26) by ex situ falling-sphere viscometry, based on examination of probing sphere positions in quenched samples. The viscosity values thus obtained, 5.7 $\mathrm{Pa}$ at $1,200^{\circ} \mathrm{C}$ and $0.8 \mathrm{Pas}$ at $1,300^{\circ} \mathrm{C}$, are associated with large uncertainties. An in-situ viscosity measurement using synchrotron $\mathrm{X}$-ray radiography was carried out for potassium carbonate melts $\left(\mathrm{K}_{2} \mathrm{Mg}\left(\mathrm{CO}_{3}\right)_{2}\right.$ and $\left.\mathrm{K}_{2} \mathrm{Ca}\left(\mathrm{CO}_{3}\right)_{2}\right)$ in ref. 27. However, because $\mathrm{K}_{2} \mathrm{Mg}\left(\mathrm{CO}_{3}\right)_{2}$ has a structure distinct from other carbonate melts as evidenced by glass formation on quenching ${ }^{28}$, it likely does not represent typical carbonate melts. In addition, the frame rate employed for capturing images of the falling sphere during these experiments was insufficient to accurately define the terminal velocity, which is the basis for viscosity determination.

Here we investigate viscosities of liquid calcite $\left(\mathrm{CaCO}_{3}\right)$ and natural dolomite $\left(\left(\mathrm{Mg}_{0.40} \mathrm{Fe}_{0.09} \mathrm{Ca}_{0.51}\right) \mathrm{CO}_{3}\right)$ up to $6.2 \mathrm{GPa}$ using an advanced technique of viscosity measurement with ultrafast synchrotron X-ray imaging. The imaging rate of 1,000 frames per second (f.p.s.), more than 15 times faster than that of conventional X-ray radiography (typically 30-60 f.p.s.) in large volume presses, enables us to precisely determine very low viscosity values. We find that viscosities of calcite and dolomite melts are surprisingly low, in the range of 0.006$0.010 \mathrm{Pas}$, which are 1-3 orders of magnitude lower than those determined in previous experiment ${ }^{26}$ and calculation ${ }^{29}$. These viscosities are so low that they are more similar to water ${ }^{30}$ than to silicate melts ${ }^{20}$. Gravity-driven melt transportation (that is, without considering effects of shear deformation) is proportional to 'hydrostatic melt mobility', $\Delta \rho / \eta$, where $\eta$ is the viscosity of the melt and $\Delta \rho$ is density contrast between the melt and the surrounding solid rock, in addition to the permeability of the $\operatorname{rock}^{20,31,32}$. We find that the mobility of carbonate melts is $\sim 2-3$ orders of magnitude higher than that of basalt melts ${ }^{20}$. Highly mobile carbonate melts should play an important role in several magmatic processes in the Earth's upper mantle, such as fast melt migration and effective melt extraction underneath mid-ocean ridges.

\section{Results}

Falling-sphere viscosity measurement by ultrafast imaging. High-pressure viscosity measurements were conducted using a Paris-Edinburgh cell installed at Beamline 16-BM-B, HPCAT, at the Advanced Photon Source (Supplementary Fig. 1). Falling velocity of the probing sphere was measured by ultrafast X-ray radiography using a high-speed camera with a 1,000 f.p.s. recording rate (exposure time of $1 \mathrm{~ms}$ ). Supplementary Movie 1 shows a representative example of a falling Pt sphere in dolomite melt at $3.0 \mathrm{GPa}$ and $\sim 1,410^{\circ} \mathrm{C}$, in real time. Supplementary Movie 2 is the same movie but at a speed that is five times slower. Figure 1 shows a series of selected images of the Pt sphere at various times during the fall, as well as the sphere travel distance and speed as a function of elapsed time. The viscosity $(\eta)$ was calculated with the Stokes equation including the correction factors for the effect of the wall $(F)^{33}$ and for the end effect $(E)^{34}$ :

$$
\begin{gathered}
\eta=\frac{g d_{s}^{2}\left(\rho_{s}-\rho_{l}\right)}{18 v} \frac{F}{E} \\
F=1-2.104\left(\frac{d_{s}}{d_{l}}\right)+2.09\left(\frac{d_{s}}{d_{l}}\right)^{3}-0.95\left(\frac{d_{s}}{d_{l}}\right)^{5} \\
E=1+\frac{9}{8} \frac{d_{s}}{2 Z}+\left(\frac{9}{8} \frac{d_{s}}{2 Z}\right)^{2}
\end{gathered}
$$

where $v$ is the terminal velocity of the probing sphere, $\rho$ and $d$ are density and diameter, with subscripts $s$ and $l$ denoting properties of the probing spheres and liquid, respectively. $Z$ is total height of the molten sample. With such a high-speed camera, the motion of the falling sphere could be monitored with substantial oversampling, enabling us to determine the terminal velocity accurately. Although the distance versus time plot (Fig. 1b) appears to show a large linear segment, careful analysis of the time derivatives shows that falling velocity reached a constant maximum (that is, terminal velocity: $11.6 \mathrm{~mm} \mathrm{~s}^{-1}$ ) within a rather limited region of the falling distance $(0.65-0.83 \mathrm{~mm})$, demonstrating that substantial oversampling is essential for terminal viscosity determination. It is difficult to measure this terminal velocity using the frame rates employed in previous falling-sphere viscosity measurements.

To illustrate this, we simulated the falling-sphere image data with a reduced frame rate of 40 f.p.s., a typical frame rate used in previous experiments. At this frame rate, a maximum of four images are recorded at $25 \mathrm{~ms}$ per point (Supplementary Fig. 2), with probing sphere falling distance forming an approximate straight line with elapsed time. Determining 'terminal' velocity through linear fitting of the falling distance data has been a commonly used methodology in previous viscosity studies. A linear fit to these four points yields a velocity $\left(9.3 \mathrm{~mm} \mathrm{~s}^{-1}\right)$, which is $\sim 20 \%$ lower than that determined by high-speed imaging (Supplementary Fig. 2), due to inappropriate sampling rate and analysis. The high frame rate used in the present study thus allows us to evaluate whether the sampling rate is sufficient to obtain a true constant velocity. Supplementary Fig. 3 shows a simulation of the falling velocity analyses with varying camera frame rates, by removing certain recorded images periodically. With decreasing camera frame rate, it becomes more difficult to define terminal velocity. At a frame rate of 250 f.p.s., it is possible to identify four data points with about the same falling velocity (Supplementary Fig. 3b). Below 100 f.p.s., however, no constant velocity region can be clearly determined (Supplementary Fig. 3ce). Since between 250 and 1,000 f.p.s. we obtain identical values for the constant falling velocity, we conclude that terminal velocity has been reached in our experiments. 
a

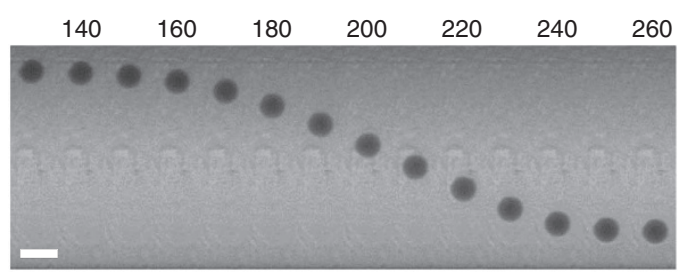

b

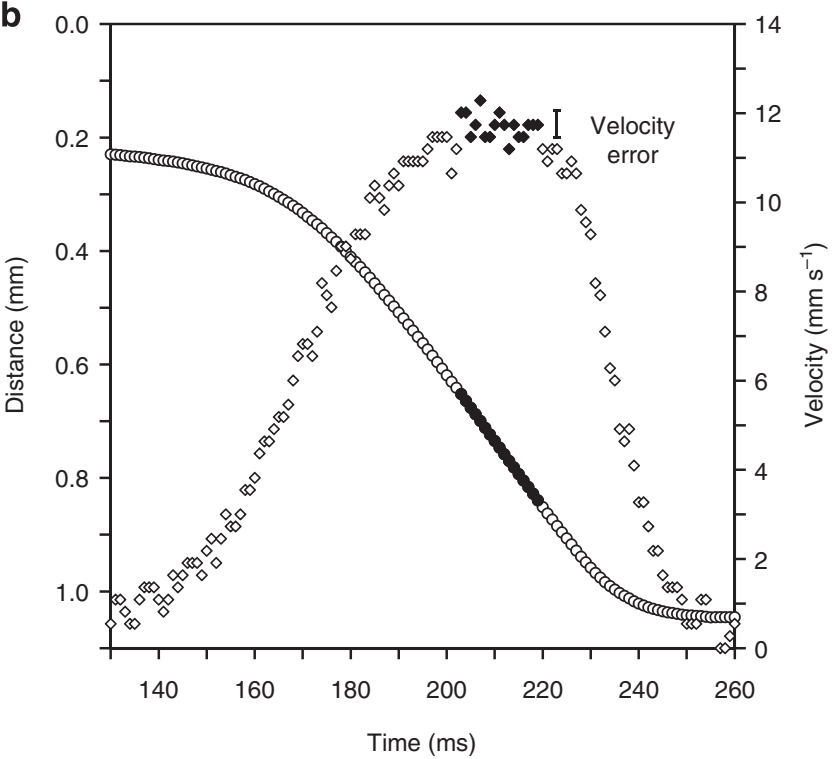

Figure 1 | Falling-sphere viscosity measurement using ultrafast X-ray imaging. (a) X-ray radiography images of falling Pt sphere $(120 \mu \mathrm{m}$ in diameter) in dolomite melt at $3.0 \mathrm{GPa}$ and $\sim 1,410^{\circ} \mathrm{C}$. Scale bar, $0.2 \mathrm{~mm}$. (b) The results of the falling distance (open circles) and the falling velocity (open diamonds) for each frame ( $1 \mathrm{~ms}$ interval). Note that terminal velocity was achieved only at limited regions of falling distance (0.65-0.83 $\mathrm{mm}$ distance, indicated by filled symbols). The data clearly show that monitoring of the motion of falling sphere with substantial oversampling by using ultrafast imaging is essential to accurately determine terminal velocity and the resultant viscosity.

Ultralow viscosity of carbonate melts. Viscosity measurements were carried out up to $6.2 \mathrm{GPa}$ at temperatures just above melting (Supplementary Fig. 4), and the results are summarized in Table 1. Figure 2 shows viscosities of calcite and dolomite melts as a function of pressure along their respective melting curves ${ }^{35,36}$. For dolomite melts, viscosities were measured at pressures $>2.9 \mathrm{GPa}$ to avoid partial melting $<\sim 3 \mathrm{GPa}$ (ref. 36). For both carbonate melts, ultralow viscosity values were obtained: 0.006-0.007 Pas for calcite melt and $0.008-0.010 \mathrm{Pas}$ for dolomite melt. These low viscosities are more similar to those of water (for example, $0.001 \mathrm{~Pa}$ s at $1 \mathrm{~atm}$ and $20^{\circ} \mathrm{C}$; ref. 30 ) than those of silicate melts ${ }^{20}$, and are 2-3 orders of magnitude lower than those reported for a 70 wt.\% $\mathrm{CaCO}_{3}-30$ wt.\% $\mathrm{MgCO}_{3}$ melt based on ex situ quench experiments (5.7 Pas at $1,200^{\circ} \mathrm{C}$ and $0.8 \mathrm{~Pa}$ s at $1,300^{\circ} \mathrm{C}$ under $1 \mathrm{GPa}$; ref. 26). A calculation based on compiled molten salt data estimated a lower viscosity of $0.08 \mathrm{~Pa} \mathrm{~s}$ at $800{ }^{\circ} \mathrm{C}$ for $\mathrm{CaCO}_{3}$ melt $^{29}$. While this is about 1 order of magnitude higher than our results, comparison between the two studies is not straightforward because the temperature of the calculation $\left(800^{\circ} \mathrm{C}\right)$ is much lower than that of our experiments $\left(1,380-1,790{ }^{\circ} \mathrm{C}\right)$ and below the melting temperature of $\mathrm{CaCO}_{3}$. The study by Dobson et al. ${ }^{27}$ reported that viscosities of potassium carbonate $\left(\mathrm{K}_{2} \mathrm{Mg}\left(\mathrm{CO}_{3}\right)_{2}\right.$ and $\left.\mathrm{K}_{2} \mathrm{Ca}\left(\mathrm{CO}_{3}\right)_{2}\right)$ melts are much lower than those of $\mathrm{Ca}-\mathrm{Mg}$ carbonate melts ${ }^{26,29}$. Our
Table 1 | Experimental conditions and the viscosity results.

\begin{tabular}{|c|c|c|c|c|}
\hline $\begin{array}{l}\text { Pressure } \\
(\mathrm{GPa})\end{array}$ & $\begin{array}{l}\text { Temperature } \\
\left.\text { ( }{ }^{\circ} \mathrm{C}\right)\end{array}$ & $\begin{array}{l}\text { Size of Pt } \\
\text { sphere } \\
(\mu \mathrm{m})\end{array}$ & $\begin{array}{l}\text { Terminal } \\
\text { velocity } \\
\left(\mathrm{mm} \mathrm{s}^{-1}\right)\end{array}$ & Viscosity (Pa s) \\
\hline \multicolumn{5}{|c|}{ Calcite $\left(\mathrm{CaCO}_{3}\right)$} \\
\hline 0.9 & 1,380 & $84 \pm 2$ & $9.1 \pm 0.3$ & $0.0067 \pm 0.0006$ \\
\hline 1.5 & 1, & $153 \pm 2$ & $28.4 \pm 0.4$ & .0003 \\
\hline 2.8 & 1,540 & $102 \pm 2$ & $14.6 \pm 0.3$ & $0.0059 \pm 0.0004$ \\
\hline 4.8 & 1,770 & $143 \pm 2$ & $25.9 \pm 0.4$ & $0.0060 \pm 0.0003$ \\
\hline 6.2 & 1,790 & $99 \pm 2$ & $13.4 \pm 0.3$ & $0.0061 \pm 0.0004$ \\
\hline \multicolumn{5}{|c|}{ Dolomite $\left(\left(\mathrm{Mg}_{0.40} \mathrm{Fe}_{0.09} \mathrm{Ca}_{0.51}\right) \mathrm{CO}_{3}\right)$} \\
\hline 3.0 & 1,410 & $120 \pm 2$ & $11.6 \pm 0.4$ & $0.0099 \pm 0.0007$ \\
\hline 3.9 & 1,400 & $94 \pm 2$ & $9.0 \pm 0.3$ & $0.0084 \pm$ \\
\hline 5.3 & 1,510 & $89 \pm 2$ & $7.7 \pm 0.2$ & $0.0087 \pm 0.0007$ \\
\hline \multicolumn{5}{|c|}{ Double-layered probing sphere measurement for dolomite } \\
\hline No data & 1,360 & $109 \pm 2$ & $8.3 \pm 0.1$ & $0.0117 \pm 0.0007$ \\
\hline 2.9 & 1,490 & $91 \pm 2$ & $10.1 \pm 0.2$ & $0.0070 \pm 0.0005$ \\
\hline
\end{tabular}

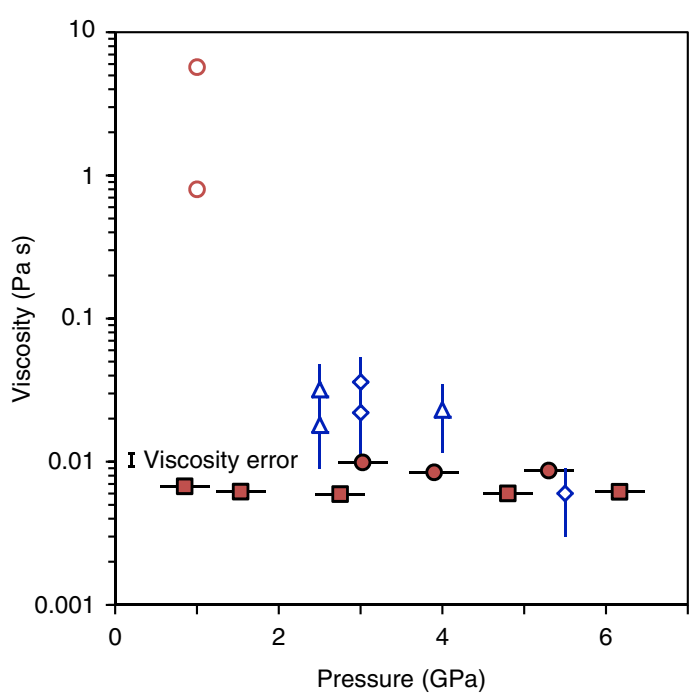

Figure 2 | Viscosities of calcite and dolomite melts. Viscosity measurements were carried out up to 6.2 GPa for calcite melts (solid dark red squares) and up to $5.3 \mathrm{GPa}$ for dolomite melts (solid dark red circles) along the melting curves. Viscosities of a 70 wt. $\% \mathrm{CaCO}_{3}-30 \mathrm{wt} . \% \mathrm{MgCO}_{3}$ melt (open dark red circles) reported by previous ex situ falling-sphere viscometry ${ }^{26}$ and those of potassium carbonate $\left(\mathrm{K}_{2} \mathrm{Mg}\left(\mathrm{CO}_{3}\right)_{2}\right.$ (open blue diamonds) and $\mathrm{K}_{2} \mathrm{Ca}\left(\mathrm{CO}_{3}\right)_{2}$ (open blue triangles)) melts ${ }^{27}$ are shown for comparison. Error of our viscosity measurement $( \pm 9.3 \%)$ is much smaller than those in ref. 27. Our obtained viscosity of calcite and dolomite melts are 2-3 orders of magnitude lower than those of previous ex situ viscosity measurements on a $70 \mathrm{wt} . \% \mathrm{CaCO}_{3}-30 \mathrm{wt} . \% \mathrm{MgCO}_{3}$ melt under $1 \mathrm{GPa}$ (ref. 26).

viscosity results for $\mathrm{CaCO}_{3}$ calcite and $\left(\mathrm{Mg}_{0.40} \mathrm{Fe}_{0.09} \mathrm{Ca}_{0.51}\right) \mathrm{CO}_{3}$ dolomite melts are even 2-6 times lower than those of potassium carbonate melts at $2.5-4.0 \mathrm{GPa}$, and are similar to the lowest value obtained at $5.5 \mathrm{GPa}$ in ref. 27. However, experimental temperatures differ between this study $\left(1,380-1,790^{\circ} \mathrm{C}\right)$ and ref. $27\left(800-1,200^{\circ} \mathrm{C}\right)$. The viscosity difference may in part be due to this temperature contrast.

Influence of temperature on viscosity of carbonate melts. The above results show that calcite melt possesses lower viscosities 
than the dolomite melt. However, since we measured the viscosities of these melts along their respective melting curves, the effects of different melting temperatures may have contributed to the difference in measured viscosities. To separate the influences of temperature and composition, we conducted an experiment using a cell assembly with a double-layered probing sphere configuration (Supplementary Fig. 1b), which allowed us to control the temperature at which the probing sphere was released. We investigated the temperature dependence of the dolomite melt viscosity at a pressure of $\sim 3 \mathrm{GPa}$. The results show that viscosity of dolomite melt is strongly temperature dependent (Fig. 3). The temperature dependence of the viscosity of dolomite melt is similar to that of potassium carbonate melts ${ }^{27}$. In contrast, ref. 26 reported much stronger temperature dependence of viscosity for the $70 \mathrm{wt} . \% \mathrm{CaCO}_{3}-30 \mathrm{wt} . \% \mathrm{MgCO}_{3}$ melt than is seen in our results.

Viscosities of dolomite and calcite melts fall on a single linear trend at $\sim 3 \mathrm{GPa}(2.8 \mathrm{GPa}$ for calcite melt, and 2.9 and $3.0 \mathrm{GPa}$ for dolomite melts; Fig. 3). Although the temperature dependence of calcite melt viscosity is uncertain, the similarity in temperature dependence of viscosities in potassium magnesium and calcium carbonate melts (ref. 27) implies that the effect of magnesiumcalcium composition on the temperature dependence of viscosity may be insignificant, and that calcite and dolomite melts possess similar temperature dependence of viscosity. The data therefore suggest that the viscosity difference between calcite and dolomite just above the melting temperature is mainly attributable to different temperature conditions, and the effect of composition on the viscosity of calcite and dolomite melts may be negligible. Even after taking the influence of temperature into account, our

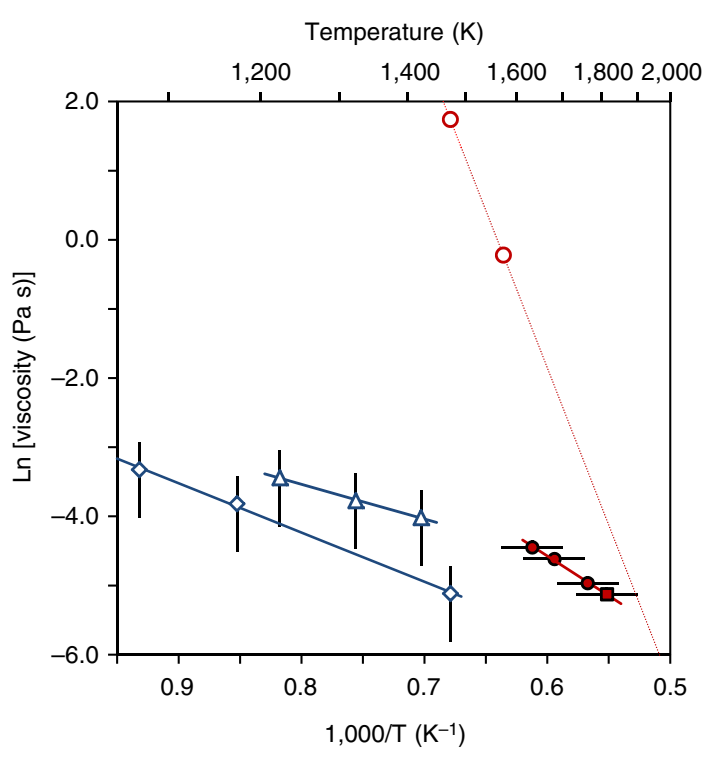

Figure 3 | Temperature dependence of viscosities of carbonate melts. The data in this study were obtained at $\sim 3 \mathrm{GPa}$ ( $2.8 \mathrm{GPa}$ for $\mathrm{CaCO}_{3}$ melt (solid dark red square) and 2.9 and $3.0 \mathrm{GPa}$ for dolomite melt (solid dark red circles)) and are compared with previous ex situ viscosity measurements ${ }^{26}$ (70 wt. $\% \mathrm{CaCO}_{3}+30$ wt. $\% \mathrm{MgCO}_{3}$ ) (open dark red circles) and those of potassium carbonate melts $\left(\mathrm{K}_{2} \mathrm{Mg}\left(\mathrm{CO}_{3}\right)_{2}\right.$ (open blue diamonds) and $\mathrm{K}_{2} \mathrm{Ca}\left(\mathrm{CO}_{3}\right)_{2}$ (open blue triangles) $)^{27}$. Vertical and horizontal bars represent error of viscosity and temperature, respectively. Our data show a strong temperature dependence of the viscosity of the dolomite melt, which explains the viscosity difference between calcite and dolomite melts just above the melting temperatures. The data imply that there is almost no effect of composition on viscosity of calcite and dolomite melts. measured viscosities of calcite and dolomite melts are much lower than those of previous ex situ viscosity measurements for $70 \mathrm{wt} . \%$ $\mathrm{CaCO}_{3}$ and $30 \mathrm{wt} . \% \mathrm{MgCO}_{3}$ (ref. 26).

\section{Discussion}

Viscosities of both calcite and dolomite melts are essentially constant at high pressures at their respective melting temperatures 35,36 . This observation is consistent with the hypothesis by Poirier $^{37}$, which suggests that viscosities of liquid metals can be scaled to the absolute melting temperature and that viscosities are constant along the melting curve with increasing pressure. We investigated the structure of the calcite and dolomite melts for each sample just after the viscosity measurement using the multiangle energy dispersive $\mathrm{X}$-ray diffraction technique ${ }^{38}$ (Fig. 4). These diffraction data show that cation-oxygen and cationcation distances of the calcite melt up to $6.2 \mathrm{GPa}$ and dolomite melt up to $5.3 \mathrm{GPa}$ are constant with increasing pressure along their melting curves, implying that there are no structural changes in these melts within our pressure and temperature range. This is likely the physical origin of constant viscosities for these melts along their melting curves.

In addition, we find almost no compositional dependence in the viscosity between calcite $\left(\mathrm{CaCO}_{3}\right)$ and dolomite melts $\left(\left(\mathrm{Mg}_{0.40} \mathrm{Fe}_{0.09} \mathrm{Ca}_{0.51}\right) \mathrm{CO}_{3}\right)$. This is in contrast to the viscosity difference between $\mathrm{K}_{2} \mathrm{Mg}\left(\mathrm{CO}_{3}\right)_{2}$ and $\mathrm{K}_{2} \mathrm{Ca}\left(\mathrm{CO}_{3}\right)_{2}$ melts (Fig. 3) noted by Dobson et al. ${ }^{27}$, who suggested a decrease in viscosity with increasing magnesium content). However, it is difficult to assess the claimed compositional effect due to the large uncertainties in their viscosity measurements (Fig. 3). In fact,

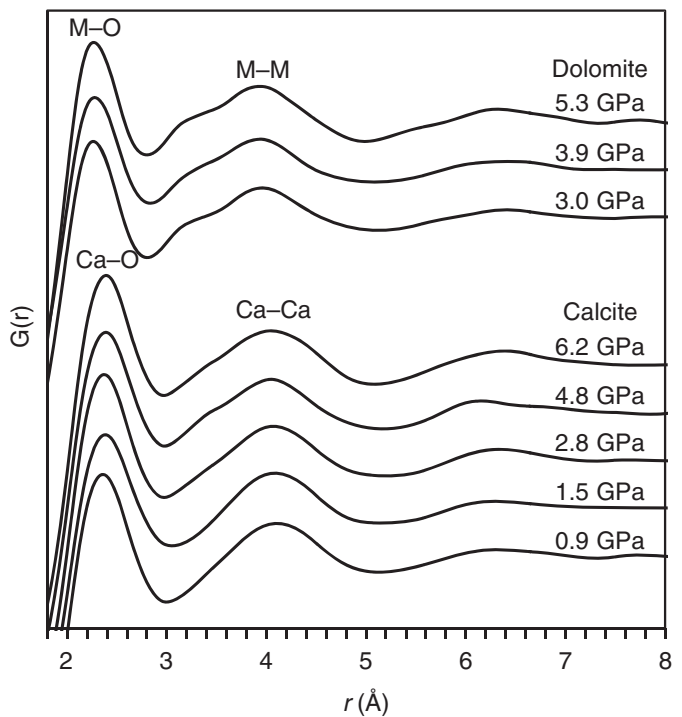

Figure 4 | Structure of calcite and dolomite melts at high pressures. The reduced pair distribution function $G(r)$ was measured using the multi-angle energy dispersive $\mathrm{X}$-ray diffraction technique $\mathrm{e}^{38}$. A molecular dynamics simulation of calcite melt showed that $\mathrm{Ca}-\mathrm{O}$ and $\mathrm{Ca}-\mathrm{Ca}$ distances of calcite melt at $0.06 \mathrm{GPa}$ and $1,327^{\circ} \mathrm{C}$ is $2.327 \AA$ and $4.173 \AA$, respectively (ref. 41). We observed similar peak positions for calcite melt that are almost constant at pressures up to $6.2 \mathrm{GPa}$ along the melting curve. In contrast, the first and second peaks of dolomite melts, which represent $\mathrm{M}-\mathrm{O}$ and $\mathrm{M}-\mathrm{M}$ distances $(\mathrm{M}=\mathrm{Ca}, \mathrm{Mg}$ and $\mathrm{Fe})$, respectively, indicate slightly shorter distances than those of calcite melts. Similarly to the calcite melt, $\mathrm{M}-\mathrm{O}$ and $\mathrm{M}-\mathrm{M}$ distances of dolomite melts also showed almost constant values up to $5.3 \mathrm{GPa}$ along melting temperatures. These data imply little structural change in the calcite and dolomite melts up to $6.2 \mathrm{GPa}$ along the melting temperatures. 
reported viscosity values of $\mathrm{K}_{2} \mathrm{Mg}\left(\mathrm{CO}_{3}\right)_{2}$ and $\mathrm{K}_{2} \mathrm{Ca}\left(\mathrm{CO}_{3}\right)_{2}$ carbonate melts are within the errors at $800-1,150^{\circ} \mathrm{C}$ and $2.5-$ $4.0 \mathrm{GPa}$, and only the data point of $\mathrm{K}_{2} \mathrm{Mg}\left(\mathrm{CO}_{3}\right)_{2}$ obtained at $5.5 \mathrm{GPa}$ and $1,200{ }^{\circ} \mathrm{C}$ showed slightly lower viscosity than the other measurements (Fig. 3). $\mathrm{K}_{2} \mathrm{Mg}\left(\mathrm{CO}_{3}\right)_{2}$ is unique among all carbonates in forming glass upon quenching 28 , which may explain the discrepancy in viscosity between $\mathrm{K}_{2} \mathrm{Mg}\left(\mathrm{CO}_{3}\right)_{2}$ and $\mathrm{K}_{2} \mathrm{Ca}\left(\mathrm{CO}_{3}\right)_{2}$ carbonate melts.

Figure 5a shows a comparison of viscosities of carbonates (calcite and dolomite) melts determined in this study and those of basalt melts reported in a previous study ${ }^{20}$ at high pressures. To estimate viscosity of carbonate melts along a geotherm ${ }^{39}$, we fit our viscosity data for both calcite and dolomite melts to a function of pressure $(P$, in GPa) and temperature (T, in Kelvin) $\left(\eta=\eta_{0} \exp \left[\frac{A+B \times P}{R\left(T-T_{0}\right)}\right]\right.$, where $\eta_{0}$ and $T_{0}$ are viscosity and temperature, respectively, at a reference condition, $R$ is the gas constant, and $A$ and $B$ are fitting coefficients) ${ }^{19}$. Since there is little composition effect on the viscosity of calcite and dolomite melts, we fit both data together, to represent viscosities of $(\mathrm{Ca}, \mathrm{Mg} \pm \mathrm{Fe}) \mathrm{CO}_{3}$ melts. We obtained parameters of $\eta_{0}=0.0045 \mathrm{Pas}, T_{0}=1,522 \mathrm{~K}, A=305$ and $B=179$ with a s.d. of $0.0007 \mathrm{Pas}$. Our obtained viscosity of carbonate melt is $\sim 90-720$ times lower than that of the basalt melt $^{20}$ at $1-6 \mathrm{GPa}$ along an adiabatic geotherm ${ }^{39}$ (Fig. 5a). The marked difference in viscosity between carbonate and basalt melts should yield a significant difference in the migration behaviour of these melts in the upper mantle.

Gravity-driven melt transportation is proportional to hydrostatic melt mobility, $\Delta \rho / \eta$, where $\eta$ is the viscosity of the melt and $\Delta \rho$ is density contrast between the melt and the surrounding solid rock, in addition to the permeability of the rock ${ }^{20,31,32}$. The study by Sakamaki et al. ${ }^{20}$ discussed the mobility of the basalt melt in the upper mantle and showed that $\Delta \rho / \eta$ changes from 0.03 to $0.58 \mathrm{~g} \mathrm{~cm}^{-3} \mathrm{~Pa}^{-1} \mathrm{~s}^{-1}$ at $0-210 \mathrm{~km}$ depth. To compare the mobility of carbonate and basalt melts, we calculated the mobility of carbonate melts by adopting the same parameters as

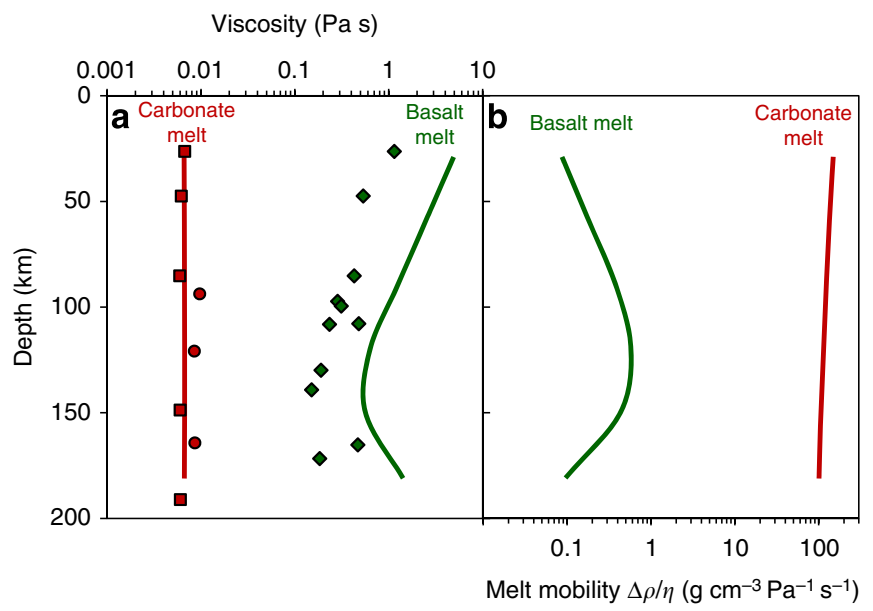

Figure $\mathbf{5}$ | Viscosity and mobility of carbonate and basalt melts. (a)

Viscosities of carbonate melts at high pressures along their melting temperatures $\left(1,380-1,790^{\circ} \mathrm{C}\right)$ (dark red symbols) compared with those of basalt melts at 1,577 and $1,827^{\circ} \mathrm{C}$ (dark green diamonds: ref. 20). The dark red and dark green lines represent viscosities of carbonate and basalt ${ }^{20}$ melts, respectively, along a geotherm ${ }^{39}$. (b) Mobility $(\Delta \rho / \eta)$ of carbonate and basalt melts ${ }^{20} . \Delta \rho$ and $\eta$ are density contrast between solid rock and melt and melt viscosity, respectively. The mobility of carbonate melt was calculated by using viscosity determined in this study and density of calcite from molecular dynamics simulation ${ }^{41}$ with density of Fo90 (ref. 40) as solid rock. Same parameters were used in the calculation of the mobility of basalt melt in ref. 20.
Sakamaki et al. $^{20}$ (adiabatic temperature gradient by Mckenzie and Bickle ${ }^{39}$, and density of Fo90 olivine by Circone and Agree ${ }^{40}$ as density of solid rock). Densities of the calcite melt at various $P-T$ conditions are based on results from molecular dynamics simulations ${ }^{41}$. Carbonate melts possess lower densities than basalt melts, further enhancing the contrast in melt mobility between basalt and carbonate melts beyond the significant differences in viscosity. As a result, the mobility of carbonate melts is $101-148 \mathrm{~g} \mathrm{~cm}^{-3} \mathrm{~Pa}^{-1} \mathrm{~s}^{-1}$ at $30-180 \mathrm{~km}$ depths, which is $\sim 200-1,700$ times higher than those of the basalt melt.

The high mobility of carbonate melts has significant implications for magmatic processes in the Earth's upper mantle. For example, melt segregation and magma focusing beneath midocean ridges is an important magmatic process that may critically depend on carbonate melt migration. A fundamental geophysical observation of the mantle beneath mid-ocean ridges is that a low degree of melt is distributed over a broad region ${ }^{42,43}$. In addition, geochemical models of melting beneath mid-ocean ridges based on radioactive isotope disequilibrium predict that melt segregates from the matrix at very low porosities on the order of $0.1 \%$ and rises $\sim 100 \mathrm{~km}$ in $1,600-8,000$ years (melt ascent velocity of $>10 \mathrm{~m}$ per year) (refs 44,45). These facts imply that small amounts of initially generated melts are efficiently extracted from the source region and transported towards the ridge axis to form the oceanic crust. However, because the basaltic melt has highviscosity $^{20}$ with low mobility, high ascent velocity $>10 \mathrm{~m}$ per year cannot be achieved by gravity-driven porous flow even by assuming the most favourable parameters for the basalt melt ${ }^{46}$. To efficiently extract and transport the highly viscous basaltic melt, several mechanisms, such as focused porous flow ${ }^{47,48}$, melt flow through open channel and/or fractures 49,50 and stress-driven melt segregation $^{51,52}$, have been proposed. On the other hand, the high melt ascent velocity may simply be achieved with liquid of much lower viscosity than that of basalt melt, such as carbonaterich melt. Faul ${ }^{46}$ argued for the possibility of volatile-rich melts at the deeper part of the mid-ocean ridge to explain high melt ascent rate at low porosities, and recent experimental ${ }^{10}$ and electrical conductivity ${ }^{12,53}$ results suggest the existence of a small amount of carbonate-rich melt in the asthenosphere beneath the midocean ridge. In addition, a geochemical study by Dasgupta et al. ${ }^{54}$ suggested that the ${ }^{230} \mathrm{Th}$ and ${ }^{231} \mathrm{~Pa}$ excesses observed in erupted mid-ocean ridge basalt are a consequence of contributions of carbonate-rich melt. These data suggest that, while basalts are erupted at mid-ocean ridges, the initial melts generated at depth in this environment may be carbonate rich, and that they progressively change to basaltic composition during ascent and melt-rock reaction ${ }^{10}$.

We calculated the migration velocity of pure carbonate melts using the following equations ${ }^{32}$ :

$$
\begin{gathered}
k=\frac{a^{2} \phi^{n}}{C}, \\
\phi w_{0}=\frac{k g \Delta \rho}{\eta},
\end{gathered}
$$

where $k$ is permeability, $a$ is characteristic grain diameter, $\phi$ is melt fraction, $n$ and $C$ are numerical constants, $g$ is the gravitational acceleration constant, and $w_{0}$ is the melt ascent velocity. We assumed $a=2 \mathrm{~mm}$ and used $n$ and $C$ values of 2 and 1,600 , respectively (according to the study by Bargen and Waff ${ }^{55}$ ). Then, the melt ascent velocity was calculated for $\phi=0.001$ with $\frac{\Delta \rho}{\eta}$ of carbonate melt obtained in this study (101$\left.1^{\eta} 48 \mathrm{~g} \mathrm{~cm}^{-3} \mathrm{~Pa}^{-1} \mathrm{~s}^{-1}\right)$. The calculation yielded a melt ascent velocity of $\sim 80-115 \mathrm{~m}$ per year, which is higher than that constrained by radioactive isotope disequilibrium $(>10 \mathrm{~m}$ per year) (refs 44,45). These data imply that the high mobility of pure 
carbonate melts can yield large enough migration velocities to satisfy constraints by radioactive isotope disequilibrium in the mantle deep beneath mid-ocean ridges.

Carbonate-rich melts are likely to be strongly reactive with the silicate mantle during upward flow, leading to progressive change in the melt composition from carbonate rich to silicate rich with decreasing depth ${ }^{10}$. The $\mathrm{CO}_{2}$ content of $\mathrm{H}_{2} \mathrm{O}$-free carbonated peridotite melt decreases to $\sim 20-25 \mathrm{wt} . \%$ upon rising to $150 \mathrm{~km}$ depth ${ }^{10}$, corresponding to a liquid with $c a .50 \mathrm{wt} . \%$ carbonate and 50 wt.\% silicate. Significant changes in melt viscosity and meltmigration velocity should accompany this compositional evolution. However, the viscosity variation between carbonate and silicate melts is poorly understood, and studies of the effect of $\mathrm{CO}_{2}$ on viscosity of silicate melts have considered only low $\mathrm{CO}_{2}$ contents (up to 3.6 wt.\%) ${ }^{56,57}$.

To assess the influence of composition on the viscosity of carbonate-rich melts, we conducted preliminary experiments on $\mathrm{CaCO}_{3}-\mathrm{CaSiO}_{3}$ melts using the same viscosity measurement technique. The results show that the logarithm of the viscosity of highly carbonated silicate melts displays a linear variation with composition across $\mathrm{CaCO}_{3}$ and $\mathrm{CaSiO}_{3}$ join (Fig. 6). If carbonate-basalt melts are characterized by a viscosity-composition trend similar to that of $\mathrm{CaCO}_{3}-\mathrm{CaSiO}_{3}$ melts, then carbonated silicate melt of $50 \mathrm{wt} . \%$ carbonate and $50 \mathrm{wt} . \%$ silicate at $150 \mathrm{~km}$ depth would possess viscosity $\sim 9.5$ times higher than pure carbonate melt, because the viscosity of carbonate melt along the geotherm is $\sim 90$ times lower than that of basalt melt ${ }^{20}$ at $120-150 \mathrm{~km}$ depth (Fig. 5). Although the $\sim 9.5$ times increase of viscosity may decrease melt-migration velocity proportionally, Dasgupta et al. ${ }^{10}$ reported that the fraction of the melt increases by about a factor of 2 from $\sim 0.025 \mathrm{wt} . \%$ at $\sim 250 \mathrm{~km}$ depth to $\sim 0.05 \mathrm{wt} . \%$ at $\sim 150 \mathrm{~km}$ depth; this proportionally decreases melt-migration velocity according to equations (4) and (5). As a result, the migration velocity of the melt at $\sim 150 \mathrm{~km}$ depth is

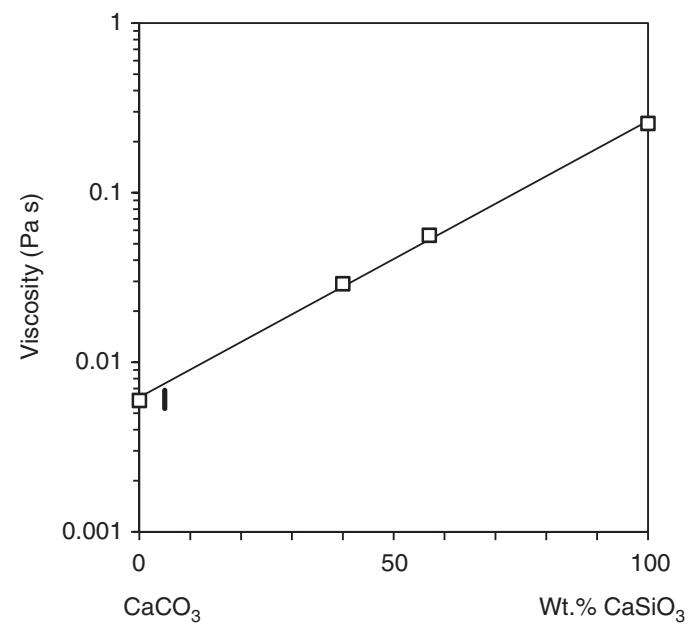

Figure 6 | Effect of composition between $\mathrm{CaCO}_{3}$ and $\mathrm{CaSiO}_{3}$ on melt viscosity. These mixtures display simple eutectic melting with no sub-solidus decarbonation reactions ${ }^{62}$, making them amenable to fallingsphere viscosity measurements. Viscosity measurements were conducted on 40,57 and 100 wt.\% $\mathrm{CaSiO}_{3}$ at almost identical pressure (2.8-3.2 $\mathrm{GPa}$ ) and temperature $\left(1,500-1,570^{\circ} \mathrm{C}\right)$ conditions. The thick vertical line represents variation of viscosity attributed to temperature variation between 1,500 and $1,570^{\circ} \mathrm{C}$ estimated from temperature dependence of viscosity of carbonate melts in Fig. 3. Viscosities of $\mathrm{CaCO}_{3}-\mathrm{CaSiO}_{3}$ melts with 40 and 57 wt.\% $\mathrm{CaSiO}_{3}$ compositions lie on a linear line of $\log _{10}$ viscosity versus wt.\% of $\mathrm{CaSiO}_{3}$ between pure $\mathrm{CaCO}_{3}$ and $\mathrm{CaSiO}_{3}$ compositions. only $\sim 4-5$ times lower than that of pure carbonate melt. It is important to note that while $\mathrm{CaSiO}_{3}$ liquids contain a mixture of network forming $\mathrm{SiO}_{2}$ and network modifying $\mathrm{CaO}$, they are nevertheless a highly simplistic model for more complex silicate liquids such as basalt. Additional viscosity measurements on such liquids are necessary to refine these calculations. Nevertheless, our experiments imply that highly carbonated silicate melt could also migrate at speeds $>10 \mathrm{~m}$ per year.

\section{Methods}

High-pressure and high-temperature experiments. Measurements were carried out in a standard Paris-Edinburgh cell assembly ${ }^{38}$ with a cylindrical sample $1.5 \mathrm{~mm}$ in diameter and $1.6 \mathrm{~mm}$ in height enclosed in a graphite capsule (Supplementary Fig. 1). The cell assembly mainly consists of a boron-epoxy gasket, $\mathrm{MgO}$ sleeve pressure medium, graphite heater and $\mathrm{ZrO}_{2}$ thermal insulation cap. The $\mathrm{ZrO}_{2}$ cap provides a good thermal insulator that reduces temperature variation in samples ${ }^{58}$. Temperatures were estimated by power-temperature relation curves that were determined in a separate experiment using an identical cell configuration ${ }^{38}$. The estimated temperatures were consistent with the melting curve of $\mathrm{CaCO}_{3}$ (ref. 35) with a s.d. of $60^{\circ} \mathrm{C}$ (Supplementary Fig. 4).

Reproducibility of the temperature calibration has been demonstrated previously ${ }^{59}$ by reproducing the melting curves of $\mathrm{NaCl}$ and $\mathrm{KCl}$ with a s.d. of $50^{\circ} \mathrm{C}$ at pressure conditions up to $7.3 \mathrm{GPa}$. The temperature gradient in the sample is uncertain, but the fact that a sphere placed at the top of the sample fell within $60^{\circ} \mathrm{C}$ from the melting temperatures of $\mathrm{CaCO}_{3}$ (ref. 35) implies that temperature gradient in the sample is not significant. Pressures were determined by the equation of state of $\mathrm{MgO}$ (ref. 60). Details of the Paris-Edinburgh cell high-pressure and hightemperature experiment are described elsewhere (ref. 38).

Ultrafast X-ray imaging. The ultrafast $\mathrm{X}$-ray imaging was carried out using unfocused white X-rays with a beam size of $1.0 \mathrm{~mm}$ (horizontal) $\times 1.0-1.3 \mathrm{~mm}$ (vertical) depending on height of the PE cell at high pressures. We employed Cedoped yttrium aluminium garnet (YAG:Ce) with a $45^{\circ}$ mirror and a five times infinity-corrected objective lens (numerical aperture $=0.14$ ). Images were captured with a high-speed camera (Photron FASTCAM SA3). The pixel resolution of $5.46 \mu \mathrm{m}$ per pixel was calibrated by using a WC ball with a $497 \mu \mathrm{m}$ diameter.

Falling-sphere viscosity measurement. Falling-sphere viscosity measurements used Pt balls with diameters ranging from $84-153 \mu \mathrm{m}$ as probing spheres (Table 1). We analyzed the position of the Pt sphere in each frame by using the Tracker plugin in the ImageJ software package. The diameter of the Pt spheres was measured by X-ray radiography using a high-resolution camera with a pixel size of $0.95 \mu \mathrm{m}$ per pixel (ref. 38). The density of the Pt spheres was calculated by the equation of state for platinum ${ }^{61}$. We used density information for the calcite melt reported by molecular dynamics simulations ${ }^{41}$. Unfortunately, the density of dolomite melt is not well-known. We therefore adopted the same density as the calcite melt in the dolomite viscosity calculation. The assumption does not significantly influence the viscosity determination because of the large difference in densities between $\mathrm{Pt}$ (for example, $21.45 \mathrm{~g} \mathrm{~cm}^{-3}$ at ambient condition) and the carbonate melts $\left(2.2-2.6 \mathrm{~g} \mathrm{~cm}^{-3}\right)$. For example, a $10 \%$ difference in the dolomite melt density would only change the viscosity by $1.3 \%$. In contrast, it is known that the uncertainties in terminal velocity dominate the precision of the viscosity determination. In this study, terminal velocities were accurately determined with s.d. of $\pm 1.4-3.9 \%$. In addition, the uncertainty in the diameter of the probing sphere also contributes to errors in viscosity due to the small sphere size. Our highresolution $\mathrm{X}$-ray radiography has a $\pm 2 \mu \mathrm{m}$ resolution in imaging ${ }^{38}$, which causes $\pm 2.1-4.1 \%$ uncertainty in viscosity. Therefore, the overall uncertainty in our viscosity determination is $< \pm 9.3 \%$.

\section{References}

1. Wooley, A. R. \& Kjarsgaar, B. A. Caronatite occurrences of the world: map and database. Geol. Surv. Can. 5769, 1-28 (2008).

2. Sasada, T., Hiyagon, H., Bell, K. \& Ebihara, M. Mantle-derived noble gases in carbonatites. Geochim. Cosmochim. Acta 61, 4219-4228 (1997).

3. Fischer, T. P. et al. Upper-mantle volatile chemistry at Oldoinyo Lengai volcano and the origin of carbonatites. Nature 459, 77-80 (2009).

4. Wallace, M. E. \& Green, D. H. An experimental determination of primary carbonatite magma composition. Nature 335, 343-346 (1988).

5. Agashev, A. M. et al. Primary melting sequence of a deep $(>250 \mathrm{~km})$ lithospheric mantle as recorded in the geochemistry of kimberlite-carbonatite assemblages, Snap Lake dyke system, Canada. Chem. Geol. 255, 317-328 (2008).

6. Yaxley, G. M. et al. The discovery of kimberlites in Antarctica extends the vast Gondwanan Cretaceous province. Nat. Commun. 4, 2921 (2013).

7. Becker, M. \& Le Roex, A. P. Geochemistry of South African on-and off-craton, Group I and Group II kimberlites: petrogenesis and source region evolution. J. Petrol. 47, 673-703 (2006). 
8. Sparks, R. S. J. et al. The nature of erupting kimberlite melts. Lithos 112, 429-438 (2009).

9. Mitchell, R. H. Experimental studies At 5-12 GPa of the Ondermatjie hypabyssal kimberlite. Lithos 76, 551-564 (2004).

10. Dasgupta, R. et al. Carbon-dioxide-rich silicate melt in the Earth's upper mantle. Nature 493, 211-215 (2013)

11. Ghosh, S., Litasov, K. \& Ohtani, E. Phase relations and melting of carbonated peridotite between 10 and $20 \mathrm{GPa}$ a proxy for alkali-and $\mathrm{CO}_{2}$-rich silicate melts in the deep mantle. Contrib. Mineral. Petrol. 167, 1-23 (2014).

12. Gaillard, F., Malki, M., Iacono-Marziano, G., Pichavant, M. \& Scaillet, B. Carbonatite melts and electrical conductivity in the Asthenosphere. Science 322, 1363-1365 (2008).

13. Sifré, D. et al. Electrical conductivity during incipient melting in the oceanic low-velocity zone. Nature 509, 81-85 (2014).

14. Dasgupta, R. \& Hirschmann, M. M. Melting in the Earth's deep upper mantle caused by carbon dioxide. Nature 440, 659-662 (2006).

15. Stagno, V., Ojwang, D. O., McCammon, C. A. \& Frost, D. J. The oxidation state of the mantle and the extraction of carbon from Earth/'s interior. Nature 493, 84-88 (2013).

16. Dasgupta, R. In gassing, storage, and outgassing of terrestrial carbon through geologic time. Rev. Mineral. Geochem. 75, 183-229 (2013).

17. Hirschmann, M. M. Partial melt in the oceanic low velocity zone. Phys. Earth Planet. Inter. 179, 60-71 (2010).

18. Turcotte, D. L. \& Schubert, G. Geodynamics (Cambridge University Press, 2002).

19. Liebske, C. et al. Viscosity of peridotite liquid up to $13 \mathrm{GPa}$ : Implications for magma ocean viscosities. Earth Planet. Sci. Lett. 240, 589-604 (2005).

20. Sakamaki, T. et al. Ponded melt at the boundary between the lithosphere and asthenosphere. Nat. Geosci. 6, 1041-1044 (2013).

21. Brazhkin, V. V. et al. Structural transformations and anomalous viscosity in the $\mathrm{B}_{2} \mathrm{O}_{3}$ melt under high pressure. Phys. Rev. Lett. 105, 115701 (2010).

22. Rutter, M. D. et al. Viscosity of liquid Fe at high pressure. Phys. Rev. B 66, 060102 (2002).

23. Terasaki, H. et al. Viscosity change and structural transition of Molten Fe at 5 GPa. Geophys. Res. Lett. 29, 1227 (2002).

24. Brazhkin, V. V., Funakoshi, K., Kanzaki, M. \& Katayama, Y. Nonviscous metallic liquid Se. Phys. Rev. Lett. 99, 245901 (2007).

25. Brazhkin, V. V., Kanzaki, M., Funakoshi, K.-i. \& Katayama, Y. Viscosity behavior spanning four orders of magnitude in As-S melts under high pressure. Phys. Rev. Lett. 102, 115901 (2009).

26. Sykes, D., Baker, M. B. \& Wyllie, P. J. Viscous properties of carbonate melts at high pressures. Abstracts, AGU Spring Meeting. 73, 372 (Montreal, Canada, 1992).

27. Dobson, D. P. et al. In-situ measurement of viscosity and density of carbonate melts at high pressure. Earth Planet. Sci. Lett. 143, 207-215 (1996).

28. Datta, R. K., Roy, D. M., Faile, S. P. \& Tuttle, O. F. Glass formation in carbonate systems. J. Am. Ceram. Soc. 47, 153 (1964).

29. Wolff, J. A. Physical properties of carbonatite magmas inferred from molten salt data, and application to extraction patterns from carbonatite-silicate magma chambers. Geol. Mag. 131, 145-153 (1994).

30. Korson, L., Drost-Hansen, W. \& Millero, F. J. Viscosity of water at various temperatures. J. Phys. Chem. 73, 34-39 (1969).

31. Connolly, J. A. D., Schmidt, M. W., Solferino, G. \& Bagdassarov, N. Permeability of asthenospheric mantle and melt extraction rates at mid-ocean ridges. Nature 462, 209-212 (2009).

32. McKenzie, D. Some remarks on the movement of small melt fractions in the mantle. Earth Planet. Sci. Lett. 95, 53-72 (1989).

33. Faxén, H. Gegenseitige Einwirkung zweier Kugeln, die in einer zähen Flüssigkeit fallen. Ark. Mat. Astr. Fys. 19, 1-8 (1925).

34. Maude, A. D. End effects in a falling-sphere viscometer. Br. J. Appl. Phys. 12, 293-295 (1961).

35. Suito, K. et al. Phase relations of $\mathrm{CaCO}_{3}$ at high pressure and high temperature. Am. Mineral. 86, 997-1002 (2001).

36. Irving, A. J. \& Wyllie, P. J. Subsolidus and melting relationships for calcite, magnesite and the join $\mathrm{CaCO}_{3}-\mathrm{MgCO}_{3} 36 \mathrm{~kb}$. Geochim. Cosmochim. Acta 39, 35-53 (1975).

37. Poirier, J. P. Transport properties of liquid metals and viscosity of the Earth's core. Geophys. J. 92, 99-105 (1988).

38. Kono, Y., Park, C., Kenney-Benson, C., Shen, G. \& Wang, Y. Toward comprehensive studies of liquids at high pressures and high temperatures: combined structure, elastic wave velocity, and viscosity measurements in the Paris-Edinburgh cell. Phys. Earth Planet. Inter. 228, 269-280 (2014).

39. McKenzie, D. \& Bickle, M. J. The volume and composition of melt generated by extension of the lithosphere. J. Petrol. 29, 625-679 (1988).

40. Circone, S. \& Agee, C. B. Compressibility of molten high-Ti mare glass: Evidence for crystal-liquid density inversions in the lunar mantle. Geochim. Cosmochim. Acta 60, 2709-2720 (1996).
41. Genge, M. J., Price, G. D. \& Jones, A. P. Molecular dynamics simulations of $\mathrm{CaCO}_{3}$ melts to mantle pressures and temperatures: implications for carbonatite magmas. Earth Planet. Sci. Lett. 131, 225-238 (1995).

42. Forsyth, D. W. et al. Imaging the deep seismic structure beneath a mid-ocean ridge: the MELT experiment. Science 280, 1215-1218 (1998).

43. Evans, R. L. et al. Asymmetric electrical structure in the mantle beneath the East Pacific Rise at $17^{\circ} \mathrm{S}$. Science 286, 752-756 (1999).

44. Rubin, K. H. \& Macdougall, J. D. ${ }^{226}$ Ra excesses in mid-ocean-ridge basalts and mantle melting. Nature 335, 158-161 (1988).

45. Richardson, C. \& McKenzie, D. Radioactive disequilibria from 2D models of melt generation by plumes and ridges. Earth Planet. Sci. Lett. 128, 425-437 (1994).

46. Faul, U. H. Melt retention and segregation beneath mid-ocean ridges. Nature 410, 920-923 (2001).

47. Kelemen, P. B., Shimizu, N. \& Salters, V. J. M. Extraction of mid-ocean-ridge basalt from the upwelling mantle by focused flow of melt in dunite channels. Nature 375, 747-753 (1995).

48. Kelemen, P. B., Hirth, G., Shimizu, N., Spiegelman, M. \& Dick, H. J. A review of melt migration processes in the adiabatically upwelling mantle beneath oceanic spreading ridges. Phil. Trans. R. Soc. Lond. A 355, 283-318 (1997).

49. Richardson, C. N., Lister, J. R. \& McKenzie, D. Melt conduits in a viscous porous matrix. J. Geophys. Res. 101, 20423-20432 (1996).

50. Rubin, A. M. Dike ascent in partially molten rock. J. Geophys. Res. 103, 20901-20919 (1998).

51. Holtzman, B. K., Groebner, N. J., Zimmerman, M. E., Ginsberg, S. B. \& Kohlstedt, D. L. Stress-driven melt segregation in partially molten rocks. Geochem. Geophys. Geosys. 4, 8607 (2003).

52. Katz, R. F., Spiegelman, M. \& Holtzman, B. The dynamics of melt and shear localization in partially molten aggregates. Nature 442, 676-679 (2006).

53. Baba, K., Chave, A. D., Evans, R. L., Hirth, G. \& Mackie, R. L. Mantle dynamics beneath the East Pacific Rise at $17^{\circ} \mathrm{S}$ : insights from the Mantle Electromagnetic and Tomography (MELT) experiment. J. Geophys. Res. 111, B02101 (2006).

54. Dasgupta, R., Hirschmann, M. M., McDonough, W. F., Spiegelman, M. \& Withers, A. C. Trace element partitioning between garnet lherzolite and carbonatite at 6.6 and $8.6 \mathrm{GPa}$ with applications to the geochemistry of the mantle and of mantle-derived melts. Chem. Geol. 262, 57-77 (2009).

55. Bargen, N. \& Waff, H. S. Permeabilities, interfacial areas and curvatures of partially molten systems: results of numerical computations of equilibrium microstructures. J. Geophys. Res. 91, 9261-9276 (1986).

56. White, B. S. \& Montana, A. The effect of $\mathrm{H}_{2} \mathrm{O}$ and $\mathrm{CO}_{2}$ on the viscosity of sanidine liquid at high pressures. J. Geophys. Res. 95, 15683-15693 (1990).

57. Bourgue, E. \& Richet, P. The effects of dissolved $\mathrm{CO}_{2}$ on the density and viscosity of silicate melts: a preliminary study. Earth Planet. Sci. Lett. 193, 57-68 (2001).

58. Leinenweber, K. D. et al. Cell assemblies for reproducible multi-anvil experiments (the COMPRES assemblies). Am. Mineral. 97, 353-368 (2012).

59. Kono, Y., Kenney-Benson, C., Park, C., Shen, G. \& Wang, Y. Anomaly in the viscosity of liquid $\mathrm{KCl}$ at high pressures. Phys. Rev. B 87, 024302 (2013).

60. Kono, Y., Irifune, T., Higo, Y., Inoue, T. \& Barnhoorn, A. P-V-T relation of $\mathrm{MgO}$ derived by simultaneous elastic wave velocity and in situ X-ray measurements: a new pressure scale for the mantle transition region. Phys. Earth Planet. Inter. 183, 196-211 (2010).

61. Dorogokupets, P. I. \& Dewaele, A. Equations of state of $\mathrm{MgO}, \mathrm{Au}, \mathrm{Pt}, \mathrm{NaCl}-\mathrm{B1}$, and NaCl-B2: Internally consistent high-temperature pressure scales. High Press. Res. 27, 431-446 (2007).

62. Lee, W. J., Huang, W. L. \& Wyllie, P. Melts in the mantle modeled in the system CaO-MgO-SiO ${ }_{2}-\mathrm{CO}_{2}$ at $2.7 \mathrm{GPa}$. Contrib. Mineral. Petrol. 138, 199-213 (2000).

\section{Acknowledgements}

We acknowledge Vincenzo Stagno and three anonymous reviewers for valuable comments. This study was performed at HPCAT (Sector 16), Advanced Photon Source (APS), Argonne National Laboratory. HPCAT operations are supported by DOE-NNSA under Award No. DE-NA0001974 and DOE-BES under Award No. DE-FG0299ER45775, with partial instrumentation funding by the NSF. The Advanced Photon Source is a U.S. Department of Energy (DOE) Office of Science User Facility operated for the DOE Office of Science by Argonne National Laboratory under Contract No. DEAC02-06CH11357. The Paris-Edinburgh cell programme is partly supported by COMPRES. Y.W. acknowledges the NSF grant EAR-1214376. D.H. and C.E.M were supported by the Deep Carbon Observatory. A.K. acknowledges the NSF EAR-0969033 and the DOE-BES DE-FG02-10ER16136.

\section{Author contributions}

Y.K. and G.S. devised the project, and wrote the paper with input from all co-authors. Y.K., C.K.-B., C.P., G.S. and Y.W. developed the advanced viscosity measurement combined with Paris-Edinburgh cell. Y.K. carried out the experiments for calcite and dolomite melts with support from C.K.-B., D.H., A.K., and C.E.M. carried out viscosity 
measurements for $\mathrm{CaCO}_{3}-\mathrm{CaSiO}_{3}$ melts. H.O. conducted the scanning electron microscope analysis on the dolomite starting material and run products. All authors discussed the results on the manuscript.

\section{Additional information}

Supplementary Information accompanies this paper at http://www.nature.com/ naturecommunications
Competing financial interests: The authors declare no competing financial interests.

Reprints and permission information is available online at http://npg.nature.com/ reprintsandpermissions/

How to cite this article: Kono, Y. et al. Ultralow viscosity of carbonate melts at high pressures. Nat. Commun. 5:5091 doi: 10.1038/ncomms6091 (2014). 